

\section{SCHEDULING IRRIGATION FOR EARLY POTATOES}

- Find out what soil type you have on your farm by referring to a soil map of your county or by consulting your local agriculture representative.

- Measure rainfall with a rain gauge every day and record the amount falling from May 15 until the crop is harvested.

- Irrigate so that your crop receives the following amounts of water :

Fox sandy loam ....... 1 inch every 7 days

Harrow sandy loam ...... 11/5 inches every 8 days

Berrien sandy loam ...... $11 / 3$ inches every 9 days

Tuscola fine sandy loam... $11 / 2$ inches every 10 days

\section{CONTENTS}

The Value of Irrigating Early Potatoes ............................................. 3

The Supply of Irrigation Water ........................................................ 4

Water Sources ................................................................................ 4

Quality of Water ................................................................... 5

Water Temperature ................................................................... 5

Irrigation During the Middle of the Day ........................................... 5

Determining Irrigation Needs ......................................................... 5

Irrigation Schedules .................................................................. 5

A Sample Schedule for Berrien Sandy Loam .............................. 6

Schedules Tested on Fox Sandy Loam ....................................... 7

Moisture Meter Readings ............................................................. 8

Measurement of Soil Moisture by Tensiometer ......................... 10

Evaporation Measurements .......................................................... 11

Cultural Practices for Irrigated Potatoes ........................................ 12

Insect and Disease Control ..................................................... 12

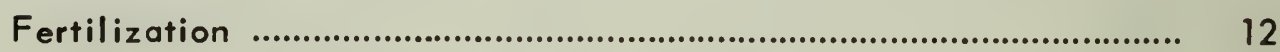

Fertilizers Through the Irrigation System ............................... 13

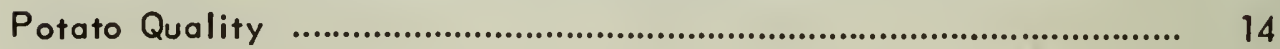




\title{
IRRIGATING SCHEDULES FOR EARLY POTATOES IN SOUTHWESTERN ONTARIO
}

\author{
J. M. Fulton \\ Research Station, Harrow, Ontario
}

\section{THE VALUE OF IRRIGATING EARLY POTATOES}

Application of irrigation water through sprinkler systems has rapidly become an accepted farming practice on the coarse-textures soils of southwestern Ontario. High temperatures and poor distribution of rainfall combine to create the need for irrigation, and the high acre-value of such crops as early potatoes provides the economic incentive. The recommendations presented here are based on research conducted at the Research Station, Harrow, Ontario, and apply specifically to conditions on the coarse-textured soils of southwestern Ontario.

Early potatoes are usually planted in early April and harvested in late June or early July. The crop grows slowly for the first six to eight weeks, normally attaining a height of about 6 inches by late May. During the next six weeks growth is very rapid, and yields as high as 300 bushels per acre have been harvested late in June. A soil moisture deficiency at this time, even for a few days at a time, has been shown to seriously retard growth of the early potato crop. The high temperatures characteristic of this period, when the vines and tubers are growing fast, result in rapid depletion of soil moisture reserves. This condition, together with the normally poor distribution of rainfall during May and June, makes supplemental irrigation of the early potato crop a profitable practice in most years.

As Table 1 shows, yield of the unirrigated potato crop at Harrow varied between a low of 85 bushels per acre in the dry season of 1963 and a high of 355 bushels per acre in 1958. The irrigated crop produced good yields every year. Response to irrigation varied greatly from one year to the next depending upon the amount of rainfall received in May and June.

The data in Table 1 was obtained from experiments on Fox sandy loam soil, which is one of the driest in the district. Response to irrigation on some of the darker-colored sandy loams would be considerably less because these soils store more water in the root zone. An estimate of the percentage of the years that each soil type would require irrigation to produce maximum yield of potatoes is given in Table 2. To determine the soil type on which your farm is located consult your agricultural representative or experiment station.

Farmers located on Tuscola fine sandy loam do not need to irrigate as of ten as those on some other soil types. In about one third of the seasons, 
Table 1. Comparison of annual yields from irrigated and nonirrigated land at Harrow from 1953 to 1964

\begin{tabular}{cccc} 
& \multicolumn{3}{c}{ Bushels per acre } \\
\cline { 2 - 4 } Year & Nonirrigated & Irrigated & Increase \\
\hline $1953 \ldots \ldots \ldots$ & 141 & 269 & 128 \\
$1954 \ldots \ldots$ & 94 & 213 & 119 \\
$1955 \ldots \ldots \ldots$ & 223 & 255 & 32 \\
$1956 \ldots \ldots$ & 177 & 259 & 82 \\
$1957 \ldots \ldots$ & 292 & 338 & 46 \\
$1958 \ldots \ldots$ & 355 & 473 & 118 \\
$1959 \ldots \ldots$ & 107 & 278 & 171 \\
$1960 \ldots \ldots$ & 340 & 433 & 93 \\
$1962 \ldots \ldots$ & 187 & 352 & 165 \\
$1963 \ldots \ldots$ & 85 & 300 & 215 \\
$1964 \ldots \ldots$ & 145 & 315 & 170 \\
Average ..... & 195 & 317 & 122 \\
\hline
\end{tabular}

Table 2. Percentage of years requiring irrigation

\begin{tabular}{|c|c|}
\hline Soil type & Percentage \\
\hline 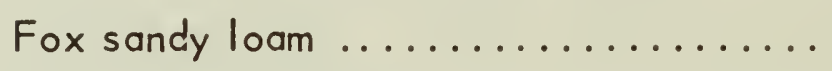 & 100 \\
\hline Harrow sandy loam........ & 95 \\
\hline Berrien sandy loam $\ldots \ldots \ldots \ldots \ldots$ & 72 \\
\hline Tuscola fine sandy loam $\ldots \ldots \ldots \ldots \ldots$ & 66 \\
\hline
\end{tabular}

rainfall plus water stored in this soil is enough to produce a good crop of potatoes. Similarly, the Harrow and Berrien sandy loams do not need to be irrigated as often as the Fox sandy loam.

\section{THE SUPPLY OF IRRIGATION WATER}

\section{Water Sources}

In southwestern Ontario, water for irrigation may be drawn from lakes, streams, farm ponds, dugout ponds, shallow wells and deep wells. Any of these sources is satisfactory for irrigating early potatoes, provided the supply is sufficient for the acreage involved. Deep wells are a good source of water, provided a coarse-textured, water-bearing stratum can be found. In 
the past, wells drilled into bedrock have generally failed to produce sufficient water for irrigation. However, a number of high-capacity wells have been developed in the Harrow district at reasonable cost during recent years.

\section{Quality of Water}

Few cases of poor water quality have been reported. The most important single factor in determining water quality is salt concentration. The concentration of soluble salts in irrigation water can be readily determined in the laboratory by means of electrical conductance equipment. Most soiltesting laboratories have the equipment necessary for making these tests.

\section{Water Temperature}

Irrigation farmers sometimes become concerned about the temperature of the water they use, but this is of little importance. Most underground sources supply water at temperatures ranging from $48^{\circ}$ to $52^{\circ} \mathrm{F}$, al though surface supplies may be much warıner, depending upon weather conditions. Research workers have been unable to show any ill effects from the use of cool water for sprinkler irrigation. This may be because much of the water from wells has its temperature increased while it is being pumped through several hundred feet of aluminum pipe and then sprayed into the air. At Harrow, water from shallow wells sprinkled on the surface has lowered soil temperatures from $82^{\circ}$ to $70^{\circ} \mathrm{F}$, but no ill effects on the foliage have been observed.

\section{IRRIGATION DURING THE MIDDLE OF THE DAY}

The application of irrigation water during the hottest parts of the day has not created any problems at Harrow. However, because wind velocities in this district are usually greatest during the middle of the day it is necessary to apply most of the water during the early morning and in the evening.

Operation of sprinkler systems when the wind is above 12 to 15 miles per hour results in poor distribution of water and therefore cannot be recommended. The wind speed that can be tolerated depends upon the volume of water discharged from each nozzle and on sprinkler spacings. These are factors that should be taken into consideration when designing a system.

\section{DETERMINING IRRIGATION NEEDS}

\section{Irrigation Schedules}

When to apply irrigation water and the quantity needed for each application are important considerations with an early potato crop. The answer to this problem depends upon the rate at which the crop uses moisture, the amount of water stored by the soil and the rainfall received. 
Recently the Research Station at Harrow has operated a group of lysimeters, which accurately measure the amount of water used each day. Highest yields have been obtained when potatoes were supplied with 1 inch of water each week; when rainfall was less than 1 inch the difference was made up by irrigation. In the dry season of 1963, rainfall supplied an average of a little less than $3 / 4$ inch per week and the yield was only 85 bushels per acre. Irrigated plots that received 1 inch per week produced 300 bushels per acre.

Fox sandy loam soil stores 1 inch of water, which is available to potatoes. This is enough water to last a week if no rain falls. Some finertextured or darker soils store more water and it lasts longer than a week.

Table 3 shows the amount of water potatoes can extract from four soil types and the number of days the supply will last. During periods when no rain falls you should base yourirrigation schedule for early potatoes on the figures given in the table.

\section{Table 3. Water available to potatoes from storage in different soils}

\begin{tabular}{lcc}
\hline \multicolumn{1}{c}{ Soil type } & $\begin{array}{c}\text { Inches of } \\
\text { water stored }\end{array}$ & $\begin{array}{c}\text { Number of tays } \\
\text { supply will last }\end{array}$ \\
\hline Fox sandy loam ........ & 1.0 & 7 \\
Harrow sandy loam ....... & 1.2 & 8 \\
Berrien sandy loam ....... & 1.3 & 9 \\
Tuscola fine sandy loan... & 1.5 & 10 \\
\hline
\end{tabular}

\section{A Sample Schedule for Berrien Sandy Loam}

If you are located on a Berrien sandy loam you should apply $11 / 3$ inches of water every nine days. The schedule should be started about mid-May, and as soon as nine days without rain have passed you should irrigate with $11 / 3$ inches of water. Nine days later another $11 / 3$ inches will be required.

Rain reduces the amount of irrigation water needed or lengthens the period between applications. For example, if $1 / 3$ inch of rain falls on the fifth day after you start keeping records, only 1 inch instead of $11 / 3$ inches will be needed on the ninth day.

A second way of handling the situation would be to allow two extra days before irrigation because the $1 / 3$ inch of rain received is enough to last another two days. By this system, you would use $11 / 3$ inches of water on the eleventh day instead of on the ninth day. The number of applications 
needed during the season will be reduced, and there will be a corresponding saving of labor for moving pipe.

\section{Schedules Tested on Fox Sandy Loam}

Fox sandy loam stores 1 inch of water, which potatoes can use without suffering a loss in yiels. This means that a crop should receive 1 inch of water every seven days or the equivalent of 0.15 inches every day. Several variations of this schedule have been tested at Harrow to make sure that calculations are right. In experiments three of the treatments supplied water at the rate of 0.15 inches per day but the number of days between applications of water was varied so that the best interval between irrigations on this soil type could be determined.

In one treatment less than 0.15 inches per day was applied and in another more water was given in order to determine the amount needed per day. In a sixth treatment no irrigation water at all was supplied, so that the crop was dependent upon rainfall only. Table 4 shows the yield of potatoes produced under each treatment.

\section{Table 4. Yield of early potatoes grown on Fox sandy loam under different irrigation schedules}

\begin{tabular}{|c|c|c|}
\hline Irrigation schedule & $\begin{array}{c}\text { Average number } \\
\text { of inches of } \\
\text { water per day }\end{array}$ & $\begin{array}{c}\text { Average } \\
\text { yield, bushels } \\
\text { per acre }\end{array}$ \\
\hline 0.60 inches every 4 days & 0.15 & 274.2 \\
\hline 1.05 inches every 7 days & 0.15 & 280.6 \\
\hline 1.50 inches every 10 days & 0.15 & 226.0 \\
\hline 0.70 inches every 7 days & 0.10 & 231.9 \\
\hline 1.40 inches every 7 days & 0.20 & 241.3 \\
\hline No irrigation & - & 199.7 \\
\hline
\end{tabular}

This experiment showed that early potatoes grown on Fox sandy loam produced highest yields when the number of days between applications of water was seven or less. Stretching the interval to ten days reduced yields considerably. When the amount of water supplied was less than 0.15 inches per day, irrigation was not very effective. It was also shown that 0.20 inches per day was not as good as 0.15 inches. Highest yields can be obtained only when exactly the right amount of water is supplied at exactly the right time. On Fox sandy loam, then, potatoes should receive 1 inch of water every week from mid-May to harvest. 


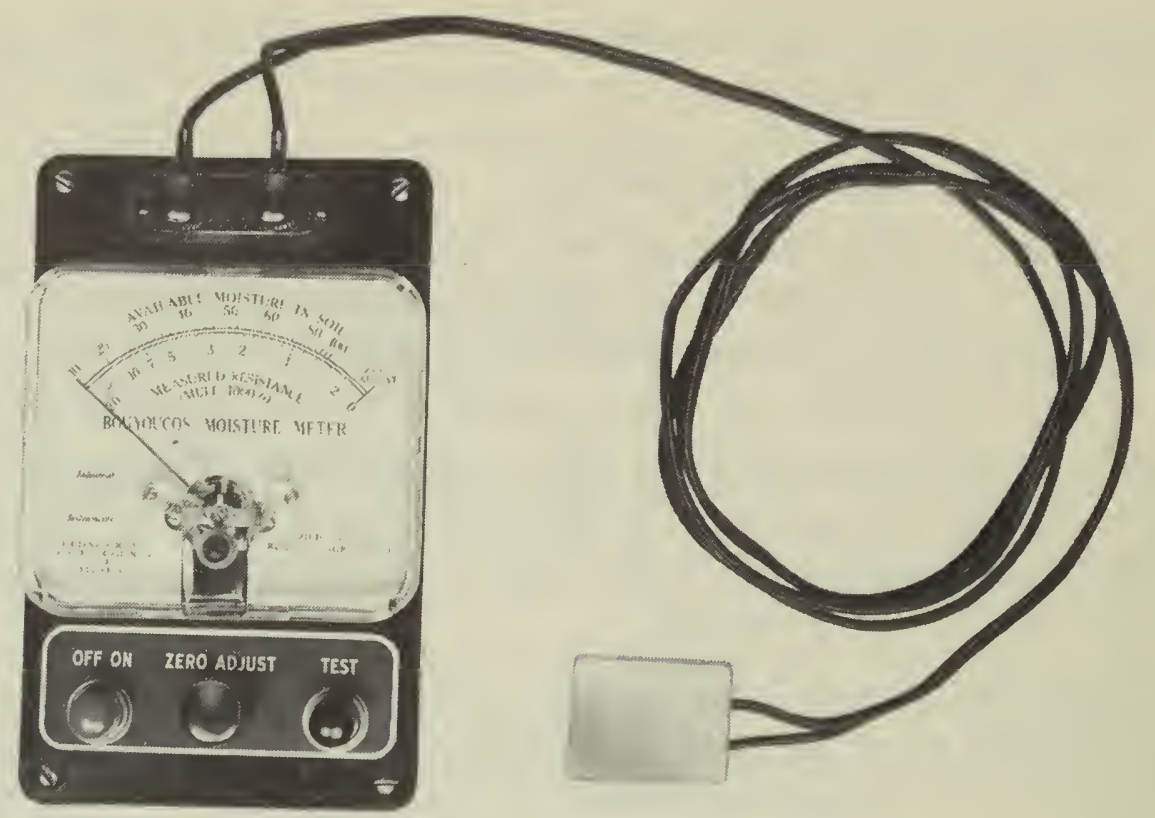

Figure 1. The Bouyoucos available moisture meter and gypsum block with 5-foot leads. The block should be buried 6 inches below the surface for an early potato crop.

\section{Moisture Meter Readings}

Probably the most reliable and efficient way to determine when to irrigate is by means of measuring the amount of moisture in the soil that is available to the growing crop. Various instruments have been developed to do this. The Bouyoucos available moisture meter with its companion gypsum blocks (Figure 1) is used extensively in irrigation research and would be valuable to potato growers although it has not yet been widely used by them.

The Bouyoucos available moisture meter is calibrated to measure the amount of available water contained in the soil as a percentage of the total that the soil can hold. For example, a reading of 100 percent is obtained when the soil contains a full supply of water under conditions of good drainage. A reading of zero is obtained when the moisture level drops to a point where a crop is unable to exert sufficient energy to get any more. To use this instrument to best advantage, the depth at which measurements should be taken and the reading at which irrigation water should be applied must be known. Experiments conducted at Harrow show that if the measurements are made 6 inches below the surface of the soil irrigation should be started when the meter reads 50 percent. The plaster blocks are placed below the soil surface with the wire leads brought above ground and attached to stakes. Each block should be located in the center of a row, below fertilizer bands and close to a growing plant. Readings are obtained by attaching the wire leads to the meter. 
At Harrow, moisture readings were taken 6 inches below the surface of a Fox sandy loam soil and irrigation water was applied when the soil still contained (1) 75 percent, (2) 50 percent, and (3) 25 percent of its full supply. Enough water was applied in each case to bring the soil up to 100 percent of its moisture-holding capacity. The yields obtained with irrigation starting at these levels of moisture and with no irrigation are compared in Table 5.

\section{Table 5. Average yield of early potatoes grown at different levels of soil moisture}

\begin{tabular}{cc}
\hline $\begin{array}{c}\text { Percentage of available } \\
\text { water in soil when } \\
\text { irrigation started }\end{array}$ & $\begin{array}{c}\text { Average yield in bushels } \\
\text { per acre 1953-1956 }\end{array}$ \\
\hline $75 \%$ & 258.8 \\
$50 \%$ & 239.9 \\
$25 \%$ & 196.3 \\
No irrigation & 117.2 \\
\hline
\end{tabular}

Any one of the three above treatments used at Harrow improved early potato yields substantially. However, if soil is allowed to dry out until only one quarter of the available moisture remains (6-inch depth), irrigation will not be so effective as when water is applied when one half of the available moisture remains. It is doubtful that the 19-bushel increase resulting from irrigation at the 75 percent full supply level would be more profitable than irrigation at the 50 percent level, because of the increased number of applications necessary.

At Harrow, the average number of potatoes set in each hill was the same in irrigated plots as in the nonirrigated area, indicating that the yield increases attributable to irrigation resulted from an increase in size of tuber rather than increased numbers. This was to be expected since the supply of available soil moisture normally stays at a high level from planting time until after tubers form. Research in other regions has shown that if the available soil moisture level drops before the time of tuber formation the number of tubers formed is reduced unless irrigation water is added.

Table 6 gives the required total irrigation water, number of applications, and number of days between applications, to obtain the yields reported in Table 5.

Since almost the same amount of water is used for the 25 percent treatment as for the 50 percent treatment it is obvious that timing is extremely 


\section{Table 6. Amount of water, average number of applications and average interval between applications under various irrigation regimes}

\begin{tabular}{cccc}
\hline $\begin{array}{c}\text { Percentage of available } \\
\text { water in soil when } \\
\text { irrigation started }\end{array}$ & $\begin{array}{c}\text { Irrigation } \\
\text { water, } \\
\text { inches }\end{array}$ & $\begin{array}{c}\text { Average } \\
\text { number of } \\
\text { applications }\end{array}$ & $\begin{array}{c}\text { Average } \\
\text { interval, } \\
\text { days }\end{array}$ \\
\hline $75 \%$ & 4.27 & 6.5 & 5.0 \\
$50 \%$ & 2.97 & 4.5 & 77.0 \\
$25 \%$ & 2.48 & 2.5 & 11.5 \\
No irrigation & 0 & 0 & - \\
\hline
\end{tabular}

important. Reasonable variations in quantity of water applied during each irrigation period are not likely to affect potato yields. However, any delay in application beyond the date when one half of the available soil moisture has been used will lower yields. Similar results obtained by Bradley and Pratt $^{1}$ at Cornell University led them to suggest that irrigating at the proper time is more important than merely irrigating. In practice the interval between applications will vary with weather conditions, being shorter than average during hot weather and longer during cool weather. However, as stated previously, seven days between applications is very effective for the early potato crop from late May to the end of June. This would probably not hold true if a crop were in the field for longer periods and therefore subject to greater variations in weather conditions.

\section{Measurement of Soil Moisture by Tensiometer}

A tensiometer is another instrument for measuring soil moisture that can be used effectively in coarse sandy loam soils. In finer-textured soils, such as loams, clay loams and clays, the tensiometer would be of little value. The essential parts of a tensiometer are a porous cup attached to the lower end of a glass tube and a gauge for measuring soil moisture tension (Table 2). The instrument is filled with water and placed in the soil at some arbitrarily selected depth. As the soil dries out suction pulls the water from the tensiometer, thereby creating a pressure deficit that is registered on the gauge. The drier the soil becomes the higher the gauge reading will be. The driest gauge reading obtainable on sandy loam soils compares with a reading of about 75 percent on the available moisture meter. Thus, this instrument can be used only while soil is still quite wet, and then only on coarse-textured soils.

\footnotetext{
${ }^{1}$ George A. Bradley and Arthur J. Pratt, Irrigate to make a crop - not to save it. Farm Research, Volume 20, No. 20, April 1954. Cornell University Agricultural Experiment Station, Ithaca, New York.
} 


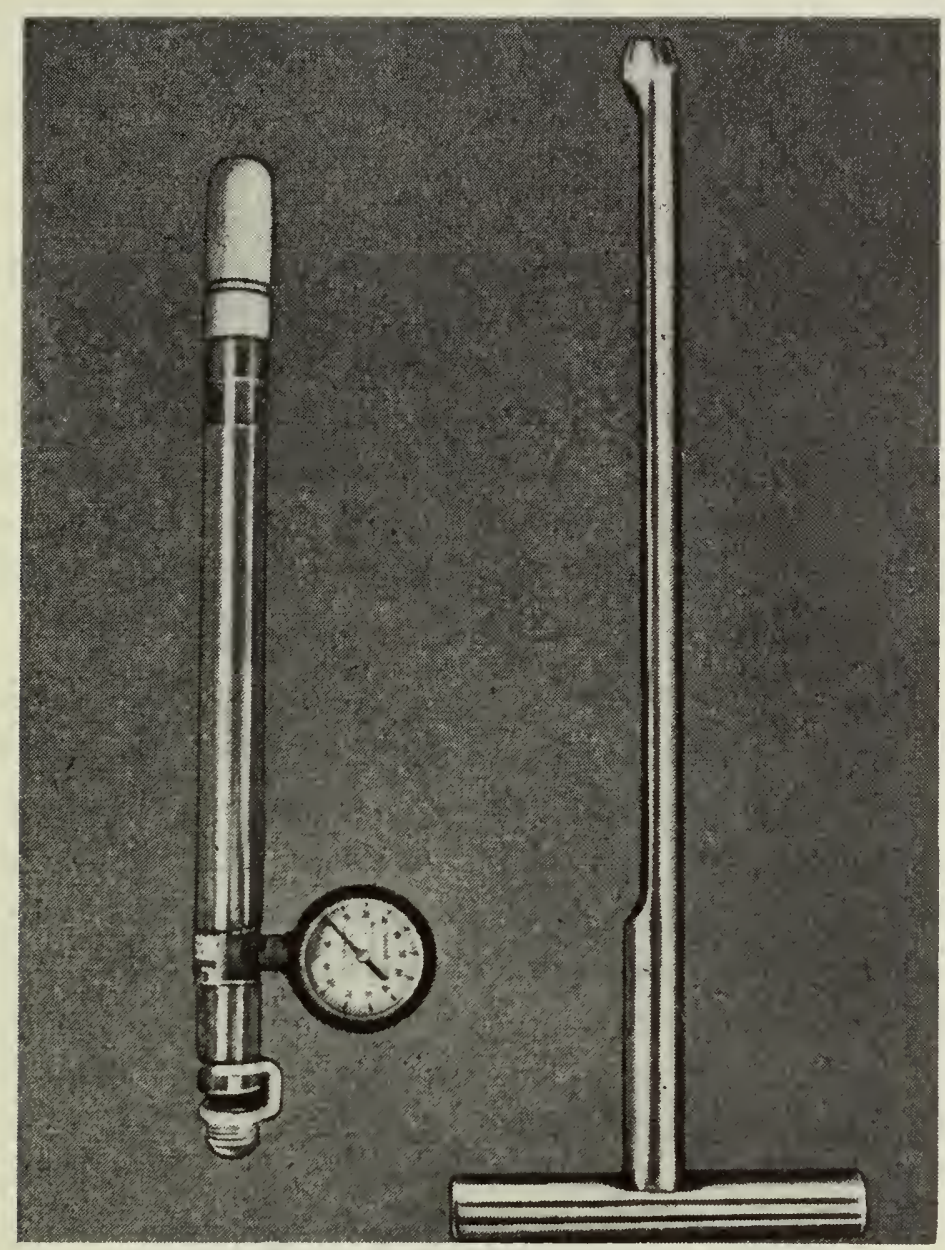

Figure 2. Left: A vacuum gauge type of tensiometer. Right: A soil sampling tube used for making an opening in which to insert a tensiometer.

\section{Evaporation Measurements}

During recent years attempts have been made to estimate irrigation water requirements from meteorological data. Several ways of doing this have been proposed, and they take into consideration such factors as temperature, hours of sunshine, radiant energy, and in some cases humidity and wind velocity. A useful device developed by scientists of the Research Branch of the Department of Agriculture at Ottawa is the atmometer which measures the "drying power" of the atmosphere. Measurements made with this instrument make it possible to estimate the amount of water used by a crop, provided soil moisture is in good supply and the crop covers the whole ground surface. The method has been found effective on irrigating fruit trees in the Okanagan Valley of British Columbia. However, considerable information is needed in addition to evaporation measurements because actual water use is usually less than the amount indicated by evaporation measurements. Corrections have to be made for the moisture content of the soil and the crop grown. Even after these corrections are made the amount 
of water the crop can extract from each soil type without suffering a loss in yield must be known. The schedules described previously are recommended because the information needed to correct evaporation measurements is not always available. The schedules are simple to use and are effective.

\section{CULTURAL PRACTICES FOR IRRIGATED POTATOES}

Almost all good cultural practices that are recommended for nonirrigated early potato production are equally applicable to irrigated crops. The spacing of seed pieces and row spacing should be the same when the crop is to be irrigated as when it is not. In general, rows 36 inches apart with seed placed 12 to 15 inches apart in each row are quite satisfactory. About 20 bushels of seed potatoes per acre are required.

The only change in cultural practice considered necessary if potatoes are to be irrigated is slightly deeper planting. The tubers will then form a little deeper in the ground and will not sunburn so readily when hilling is delayed until the plants begin to fill the row. The advantage in delaying hilling until this stage is that irrigation water distribution is poor on hilled rows. The water runs to the center of the row, resulting in dry areas around new tubers and plant roots. Since the early potato crop is usually harvested in late June and in July, only one or possibly two applications of irrigation water will be necessary after the vines completely fill the rows.

\section{INSECT AND DISEASE CONTROL}

At Harrow, insect or disease infestations have been no greater on irrigated plots than on adjoining nonirrigated areas. Whether irrigation is used or not, a good dust or spray program should be followed to control the potato beetle, flea beetle, leaf hopper and blight. Recommendations for the control of these insects and diseases are given in vegetable spray calendars published by the Ontario Department of Agriculture.

\section{FERTILIZATION}

Early potatoes are grown in southwestern Ontario as part of an intensive cropping and fertilization program. Consequently the fertility levels of most of the soils in this area are extremely high. Experiments conducted at Harrow have shown that high yields of potatoes can be obtained consistently and the fertility levels in the soil kept at a high level if the unirrigated crop is fertilized with 800 pounds of 5-10-13 per acre.

The irrigated crop produces a bigger yield, and fertility levels are depleted unless the rate of fertilization is increased. Table 7 shows that if you start with a highly fertile soil, little or no fertilizer is needed for the first irrigated or unirrigated crop. However, at Harrow, after five years 


\section{Table 7. Effect of five years of irrigation on the rate of fertilization needed for potatoes}

\begin{tabular}{rcccc}
\hline & \multicolumn{4}{c}{ Yield, bushel s per acre } \\
\cline { 2 - 5 } Pounds & \multicolumn{2}{c}{ First year } & \multicolumn{2}{c}{ Fifth year } \\
\cline { 2 - 5 } $5-10-13$ & \multicolumn{1}{c}{ Irrigated } & Not irrigated & Irrigated & Not irrigated \\
& 184 & 138 & 166 & 173 \\
40 & 217 & 165 & 367 & 305 \\
800 & 177 & 138 & 375 & 331 \\
1,600 & 200 & 154 & 415 & 327 \\
\hline
\end{tabular}

400 to 800 pounds of 5-10-13 was adequate for an unirrigated crop although at least 1,600 pounds per acre was needed for an irrigated crop.

\section{Fertilizers Through Irrigation Systems}

With the exception of phosphatic materials, practically all fertilizer nutrients are easily soluble and can therefore be added through irrigation systems. Soluble phosphate materials are too expensive to permit adding them through a sprinkler system.

Normally it is best to apply some of the nitrogen, all of the phosphorus and most of the potassium needed by a crop at planting time. However, as the season progresses it may become evident that the fertilizers added at or before planting were inadequate. When this situation occurs it is a sound practice to apply nitrogen or potash materials, or both, through the sprinkler system. Ammonium nitrate, ammonium sulphate and sodium nitrate are all soluble and are therefore suitable sources of nitrogen. Liquid nitrogen fertilizers can be used effectively, provided they do not contain any free ammonia gas. When materials containing free ammonia gas are applied through an irrigation system there is a high loss of ammonia nitrogen to the atmosphere and in addition there is danger of burning the foliage. For these reasons materials such as anhydrous ammonia cannot be applied in irrigation water.

Potassium fertilizer materials are readily dissolved in water and can therefore be applied effectively in irrigation water. However, since potassium is not readily leached from the soil and is not subject to severe fixation, there is perhaps little reason for applying potassium salts through irrigation systems unless it becomes obvious that the requirement of the potatoes has not been satisfied at planting time. 


\section{POTATO QUALITY}

In the Harrow experiments, irrigation had no effect on the dry matter content of potato tubers. In 1960 the dry matter content of the irrigated crop was 19.2 percent and the unirrigated crop 19.5 percent. Unfertilized plots produced tubers with higher dry matter content than plots fertilized with 800 or 1,600 pounds of fertilizer per acre. However, this improvement in dry matter content was obtained at the expense of a 150 bushel per acre yield reduction on the unirrigated crop and a 250 bushel per acre yield reduction on irrigated plots. 


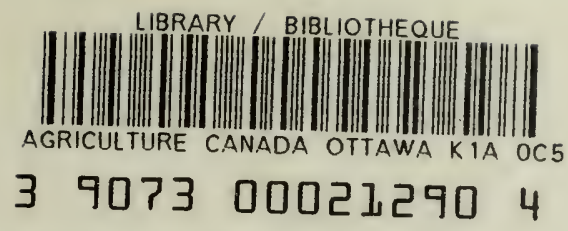


Copies of this publication may be obtained from:

INFORMATION DIVISION

CANADA DEPARTMENT OF AGRICULTURE

OTTAWA

A revision of Irrigating Early Potatoes in Southwestern

Ontario, Publication 1028, 1958. 